\title{
ISMILeSys: APLIKASI PENGOLAHAN NILAI
}

\author{
Luh Putu Cintya Prabandari \\ Jurusan Teknik Media Digital \\ Institut Teknologi Bandung \\ Bandung, Indonesia \\ e-mail : cintyaprabandari@gmail.com
}

\begin{abstract}
Abstrak
Pembelajaran secara online menjadi salah satu sarana yang efektif untuk melaksanakan perkuliahan. Batas, ruang dan waktu dapat diatasi dengan adanya sistem pembelajaran secara online sehingga efektifitas dan efisiensi dapat tercapai. Secara umum, pembelajaran online memuat materi pembelajaran dan pengumpulan tugas serta ujian. Ada beberapa hal yang pada umumnya tidak dapat dipenuhi oleh pembelajaran online seperti penilaian secara online. Dengan masalah tersebut, diperlukannya suatu perancangan sistem manajemen sekolah, informasi dan pembelajaran melalui internet. Sistem ini dimulai dari pendaftaran mahasiswa baru, melihat materi dan mengikuti ujian online dari sisi mahasiswa. Sedangkan dari sisi dosen dapat memasukkan materi, mengadakan ujian dan mengolah nilai. Dalam hal ini, penulis merancang aplikasi pengolahan nilai pada produk Integrated School Management, Information and Learning System (ISMILeSys). Bahasa pemrograman yang digunakan adalah PHP dan MySQL sebagai pengelola basis data. Dengan perancangan dan pembuatan aplikasi ini, diharapkan dapat mempermudah dosen dalam memasukkan nilai hingga menentukan nilai mahasiswa.
\end{abstract}

Kata kunci: ISMILeSys, aplikasi pengolahan nilai

\begin{abstract}
Online teaching and learning is the one of effective means to implement the course. Limits, time and space can be overcome with a system of online learning. And also, the effectiveness and efficiency can be achieved. In general, online learning includes learning materials and collection of assignments and exams. There are several things that generally can't be met such as online learning assessment through the system. With this problem, is needed to design system of school management, information and learning via internet. Starting from the registration of new student, see the module learning, online exams of the student. Entering the module by lecture, conducting examinations and processing the value that the lecture's work. In this case, particularly the author designed the application processing the value on the product of ISMILeSys (Integrated School Management, Information and Learning System). Programming language that used is PHP and MySQL as a database manager. By designing and manufacturing this application, is expected to assist faculty in the insert to determine the value of a student.
\end{abstract}

Keywords: ISMILeSys and application of grade tabulation.

\section{PENDAHULUAN}

Pesatnya kemajuan peradaban manusia salah satunya disebabkan dengan adanya temuan-temuan di bidang teknologi informasi dan komunikasi. Tidak berlebihan jika abad ini lebih dikenal sebagai abad informasi. Hal ini dikarenakan perkembangan teknologi informasi begitu pesat dan merambah ke berbagai bidang kehidupan. Teknologi informasi yang secara sederhana disimbolkan dengan perangkat komputer dan jaringan internet serta teknologi komunikasi. Dan teknologi informasi telah banyak dimanfaatkan untuk meningkatkan 
produktivitas manusia. Seiring teknologi yang berkembang, penerapan teknologi informasi atau teknologi komputer sangat diperlukan untuk mendukung pengembangan media informasi. Untuk itu melalui penelitian ini dikembangkan Integrated School Management, Information and Learning System (ISMILeSys) yang diharapkan dapat menerapkan sistem manajemen, informasi dan pembelajaran di dalam perkuliahan dan dapat digunakan secara online. Di dalam sistem ini terdapat aplikasi pengolahan nilai yang ditujukan untuk dosen. Aplikasi ini dapat membantu dosen memasukkan, memperbaiki dan mendapatkan nilai mahasiswa secara langsung dari sistem. Untuk memperjelas cakupan dari masalah ini maka diperlukan batasan masalah seperti berikut. (a) Pengguna yang dapat menggunakan aplikasi pengolahan nilai ini adalah dosen, (b) pengguna dapat memasukkan data persyaratan prosentase dan syarat batas bawah nilai dalam penentuan nilai untuk setiap mata kuliah, (c) pengguna dapat memasukkan nilai untuk setiap mahasiswa, (d) pengguna dapat mengubah nilai mahasiswa jika terdapat perubahan nilai, (e) pengguna dapat menentukan remidial untuk mahasiswa dan (f) pengguna dapat melihat daftar nilai mahasiswa. Dan manfaat yang diharapkan dari penelitian ini adalah (a) Mempermudah pengguna dalam memasukkan nilai mahasiswa, (b) mempermudah pengguna dalam menentukan nilai setiap mahasiswa dan (c) mempermudah pengguna dalam mengubah nilai setiap mahasiswa jika terdapat perubahan nilai.

\section{PERANCANGAN SISTEM}

Integrated School Management, Information and Learning System (ISMILeSys) adalah membuat materi perkuliahan online berbasiskan web dan mengelola kegiatan pembelajaran serta hasil-hasilnya. $\mathrm{Di}$ dalam ISMILeSys terdapat fitur-fitur yang dapat memenuhi kebutuhan dari pengguna dalam hal pembelajaran. Saat ini ISMILeSys menyediakan fitur-fitur yang dapat dinikmati pengguna seperti berikut : (a) Administrasi yaitu informasi tentang pengaturan pengguna serta pengaturan isi yang ada pada ISMILeSys, yang diantaranya: pembuatan menu, pembuatan matakuliah dan konsentrasi, pembuatan materi kuliah, pembuatan tugas kuliah, pembuatan kuis kuliah, pencarian materi dan tugas, pengaturan pengguna, pengolahan nilai dan keuangan; (b) Perkuliahan yaitu informasi tentang unit-unit terkait dalam proses belajar mengajar, yang diantaranya: unduh materi kuliah, unduh tugas kuliah dan pengerjaan tugas, pengerjaan kuis kuliah, pembuatan transkrip nilai, statistik nilai dan daftar hadir, pencarian materi serta tugas. Melalui ISMILeSys, mahasiswa dapat melihat transkrip nilai berdasarkan mata kuliah yang terdaftar pada mahasiswa terkait. Selain itu, mahasiswa dapat melihat materi-materi yang ditawarkan, mengambil dan mengumpulkan tugas, serta mengerjakan kuis secara online.

Adapun beberapa fungsi utama dalam ISMILeSys, yaitu dalam pembelajaran, ada banyak pihak yang terlibat: mahasiswa, dosen, sekretariat akademik dan keuangan; ISMILeSys mendukung empat pengguna utama yaitu mahasiswa, dosen, tata usaha atau sekretariat akademik dan administrator sistem; Penyimpanan data, yang meliputi nilai siswa dan data pendaftaran calon mahasiswa baru; Dapat melakukan pembayaran yang menerapkan mobile banking. Beberapa manfaat yang terdapat dalam ISMILeSys seperti sebagai berikut: Pembelajaran menjadi tidak terbatas oleh ruang dan waktu; Memudahkan dalam pengelolaan pembelajaran; Kemudahan dalam memantau kegiatan mahasiswa; Memudahkan bagi sekretariat akademik dan keuangan dalam melakukan validasi kemahasiswaan.

Gambar 1 adalah diagram alir dari perancangan sistem aplikasi pengolahan nilai pada ISMILeSys. Pengguna masuk ke menu pengolahan nilai, jika ingin memasukkan data persyaratan mata kuliah maka pengguna masuk ke menu persyaratan mata kuliah. Setelah itu, pengguna masuk ke menu masukan nilai untuk memasukkan nilai setiap 
mahasiswa sesuai dengan program dan mata kuliahnya. Setelah disimpan, pengguna dapat melihat hasil nilai di daftar nilai. Jika terdapat mahasiswa yang mendapat remidial, pengguna memilih menu remidial.

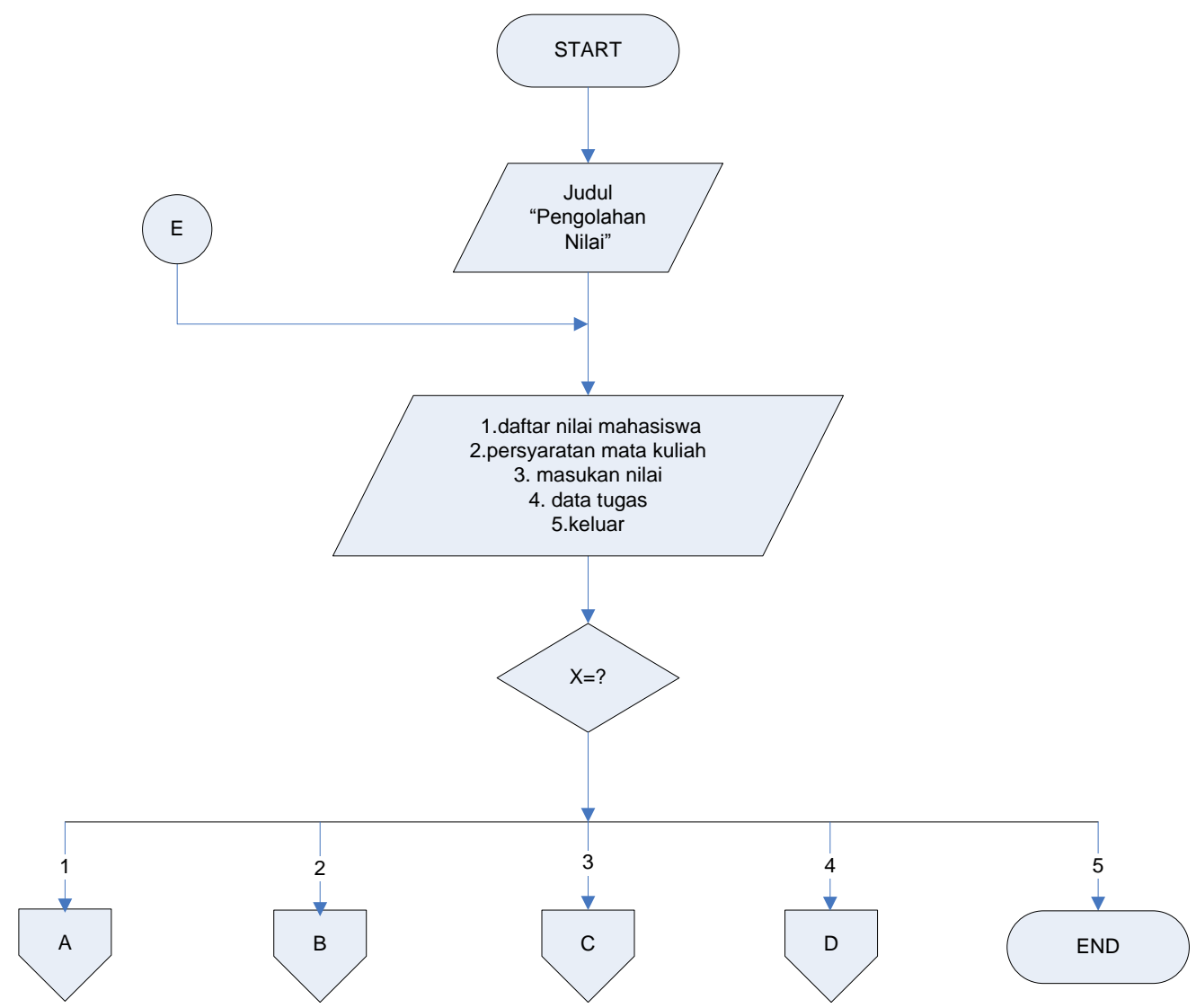

Gambar 1. Diagram alir aplikasi pengolahan nilai

Dan di daftar nilai mahasiswa, pengguna dapat memperbaiki nilai jika ada nilai yang berubah. Jika pengguna ingin memasukkan nilai maka pengguna dapat memilih menu masukan nilai. Pengguna memasukkan nilai tugas, nilai kuis, nilai UTS, nilai UAS dan nilai kehadiran. Untuk melihat data tugas, pengguna dapat melihatnya pada daftar data tugas. Pada daftar data tugas tersebut, pengguna dapat melihat data tugas seluruh mahasiswa dan apabila terdapat perubahan pada nilai tugas, pengguna dapat mengubahnya melalui form daftar data tugas. Setelah itu, apabila pengguna ingin keluar dari aplikasi pengolahan nilai maka pengguna dapat memilih menu keluar.

Pada daftar nilai mahasiswa, dosen dapat memilih menu remidial, edit dan hapus. Jika terdapat mahasiswa yang mengikuti remidial maka dosen dapat memasukkan nilai remidial dan mendapatkan nilai. Dosen dapat menentukan prosentase nilai remidial dan prosentase nilai akhir yang digunakan untuk penilaian. Jika dosen ingin mengubah nilai mahasiswa maka dosen dapat memilih menu edit dan dosen dapat mengubah nilai UTS (Ujian Tengah Semester), nilai UAS (Ujian Akhir Semester) dan nilai kehadiran. Menu hapus digunakan untuk menghapus data mahasiswa, dapat dilgunakan untuk data satu mahasiswa atau lebih maupun seluruh data mahasiswa. Dosen dapat menentukan persyaratan mata kuliah untuk prosentase masing-masing nilai yaitu nilai tugas, nilai kuis, nilai UTS, nilai UAS dan nilai kehadiran serta menentukan batas bawah nilai untuk setiap mata kuliah. dosen dapat memilih program dan mata kuliah kemudian memasukkan data prosentase nilai tugas, prosentase nilai kuis, prosentase nilai UTS, prosentase nilai UAS dan prosentase nilai kehadiran. Dosen 
dapat menentukan syarat batas bawah nilai $A$, batas bawah nilai $A B$, batas bawah nilai $B$, batas bawah nilai $B C$, batas bawah nilai
C dan batas bawah nilai D. Kemudian disimpan dan dosen dapat melihat tampilan daftar persyaratan seluruh mata kuliah.

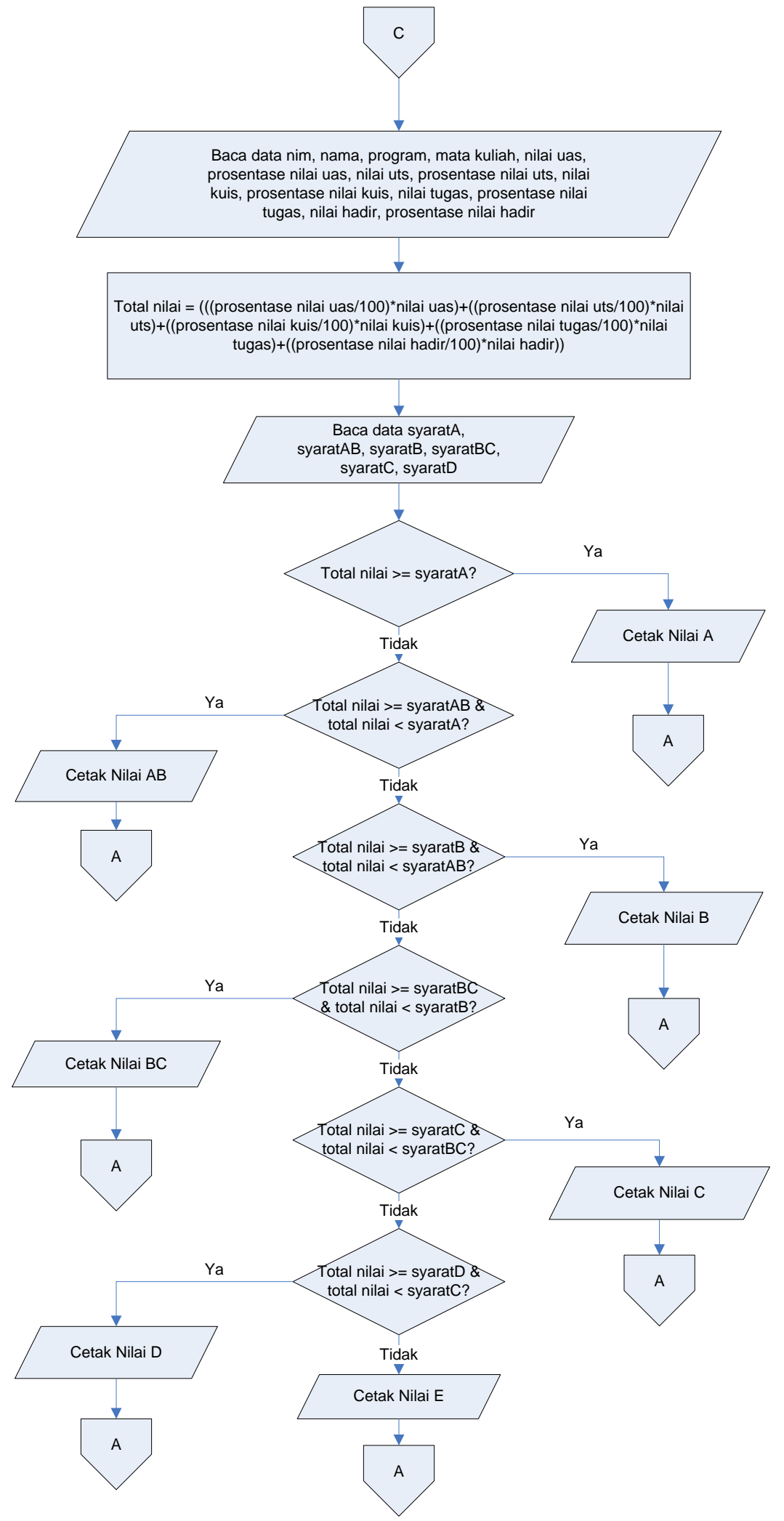

Gambar 2. Diagram alir proses masukan nilai 
Untuk proses memasukkan nilai terlihat pada gambar 2. Dosen memasukkan data nim, nama, program, mata kuliah, nilai tugas, nilai kuis, nilai UTS, nilai UAS dan nilai kehadiran. Setelah itu, nilai tersebut diproses untuk mendapatkan total nilai. Dari total nilai tersebut, ditentukan predikat sesuai dengan syarat batas bawah nilai yang telah ditentukan sebelumnya oleh dosen. Setelah proses itu, didapatkan nilai dengan predikat $A, A B, B$, BC, C atau D.

Dosen dapat mengatur data tugas dan melihat nilai setiap tugas pada daftar data tugas. Pada daftar tersebut dosen dapat mengubah nilai setiap tugas. Dosen terlebih dahulu memilih nim, nama, program dan mata kuliah kemudian mengubah nilai setiap tugas mahasiswa. Setelah itu dosen melihat daftar data tugas mahasiswa yang telah diubah sebelumnya. Tugas yang diberikan ke mahasiswa dari setiap dosen dibatasi maksimal 10 tugas untuk setiap mata kuliahnya sesuai dengan program studi.

\section{IMPLEMENTASI SISTEM}

Gambar 3 adalah halaman utama bagi pengguna sistem. Pada halaman ini penguna dapat melihat informasi yang berkaitan dengan program alih jenjang D3D4 STEI ITB dan menyediakan menu untuk pendaftaran mahasiswa baru. Terdapat menu login untuk pengguna yang telah memiliki akses.
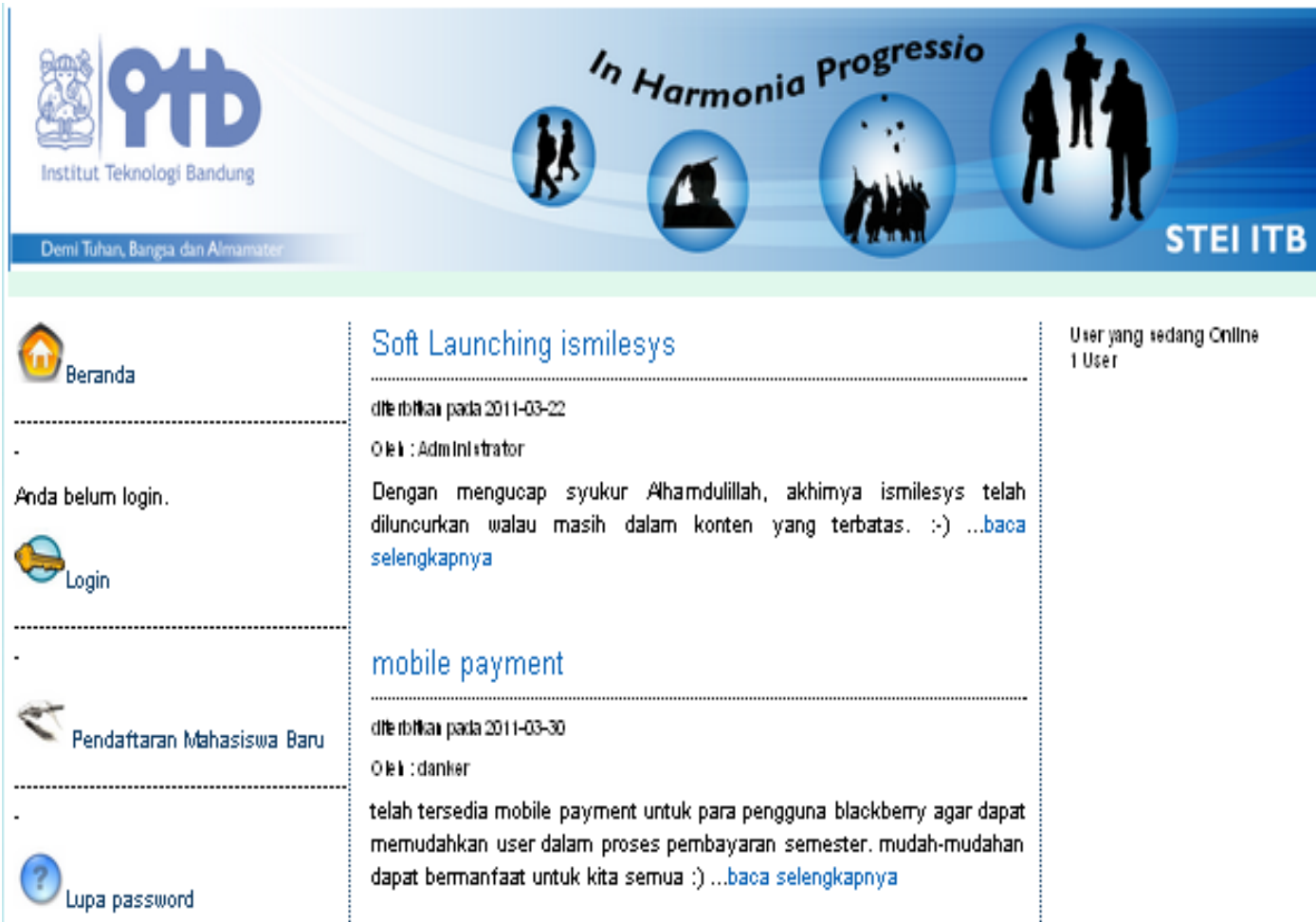

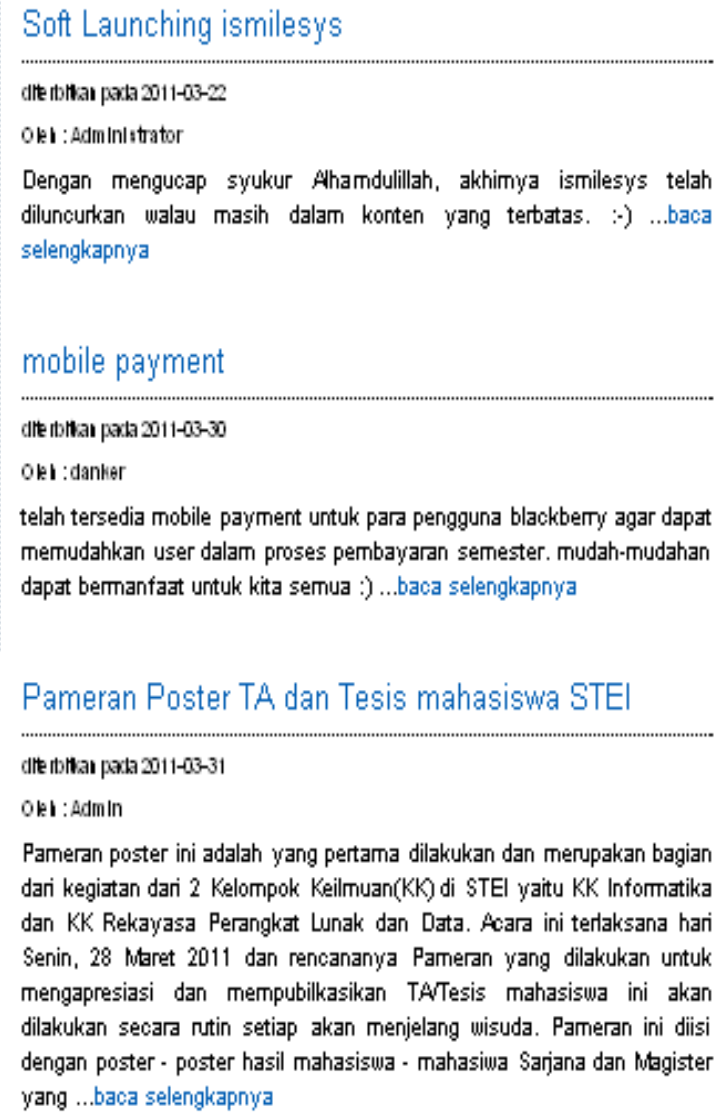

Gambar 3. Tampilan halaman utama
U:er yang sedang Colline 1 User 
Halaman pengguna melakukan login, pengguna yang telah memiliki akses diminta memasukkan username dan password. Jika username dan password yang dimasukkan salah maka terdapat pemberitahuan bahwa username atau password yang dimasukkan salah. Apabila pengguna telah logout dan kembali ke halaman utama, yang perlu dilakukan pengguna yaitu memilih link "Kembali ke HOME" dan pengguna kembali ke halaman utama. Dan pada aplikasi ini, pengguna yang memiliki akses adalah dosen. Jika username dan password yang dimasukkan benar, maka dapat langsung menuju ke halaman utama dosen, seperti yang terlihat pada gambar 4 .

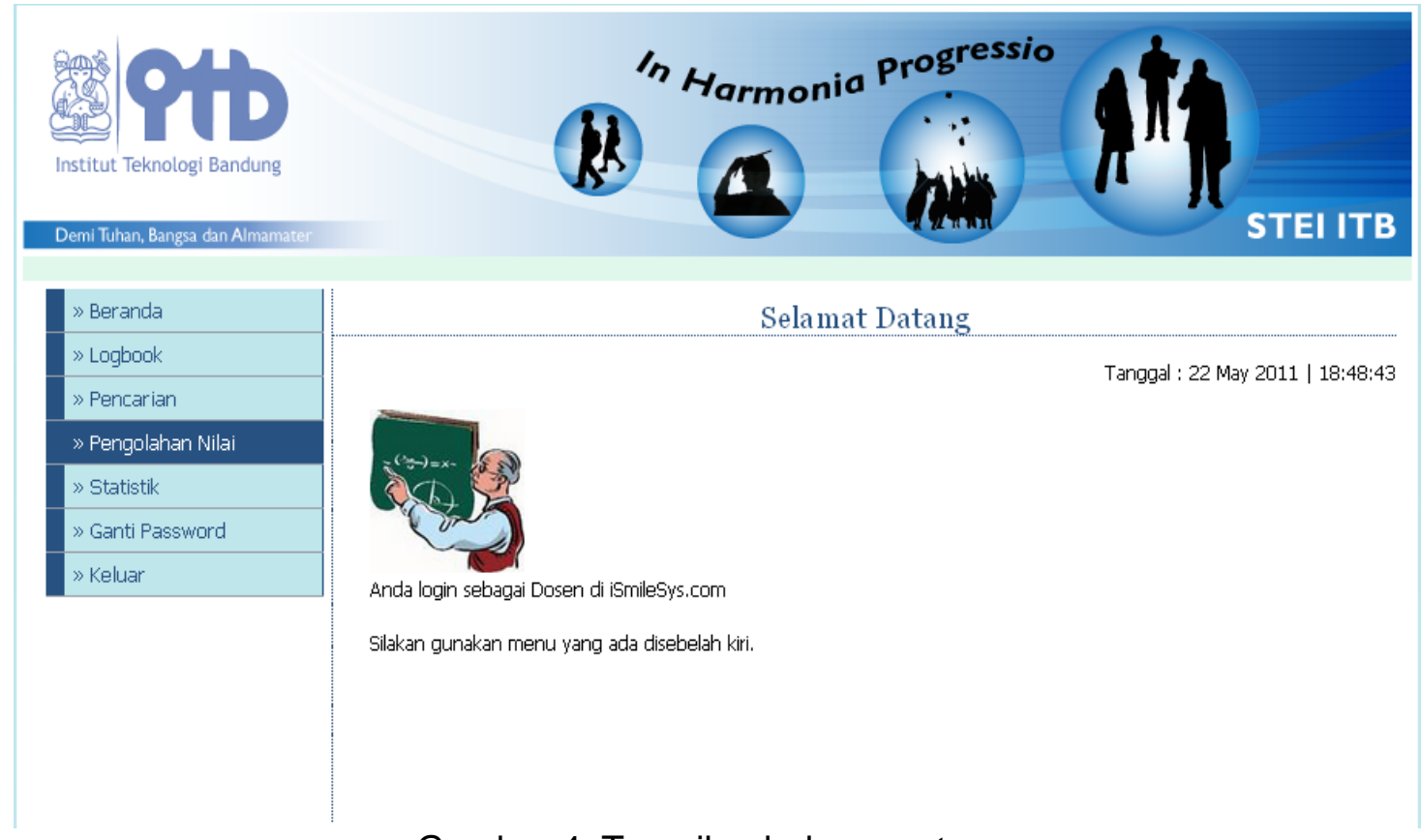

Gambar 4. Tampilan halaman utama

Pada halaman utama dosen, terdapat menu-menu yang dapat diakses oleh dosen. Setelah masuk ke halaman utama, dosen dapat mengolah nilai di menu pengolahan nilai. Pada halaman daftar nilai mahasiswa, dosen dapat melihat daftar nilai mahasiswa jika telah terisi data. Namun, jika belum terdapat data maka dosen dapat memasukkan nilai pada halaman masukan nilai.

Gambar 5 merupakan tampilan Form masukan nilai adalah menu yang bertujuan agar dosen dapat memasukkan nilai setiap mahasiswa seperti nilai tugas, nilai kuis, nilai UTS, nilai UAS dan nilai kehadiran. Form data tugas adalah menu yang berisikan daftar data tugas seluruh mahasiswa yang telah mendapatkan nilai tugas. Dan terdapat beberapa aksi seperti remidial, edit dan hapus. Aksi remidial menghubungkan dosen ke form remidial bagi mahasiswa yang mendapatkan remidi. Aksi edit menghubungkan dosen ke form perubahan nilai, dosen dapat mengubah nilai setiap mahasiswa. Aksi hapus digunakan untuk menghapus data permahasiswa. Adapun tombol hitung yang digunakan untuk predikat nilai yang belum diketahui. Tombol hapus digunakan untuk menghapus seluruh data nilai mahasiswa.

Dosen memasukkan nilai tugas, nilai kuis, nilai UTS, nilai UAS dan nilai kehadiran sesuai dengan nim, nama dan mata kuliah yang diambil mahasiswa pada form tersebut. Jika dosen memasukkan nilai mahasiswa dengan jumlah yang banyak maka dosen dapat memasukkan nilai melalui dokumen excel sesuai dengan petunjuk yang telah diberikan. 


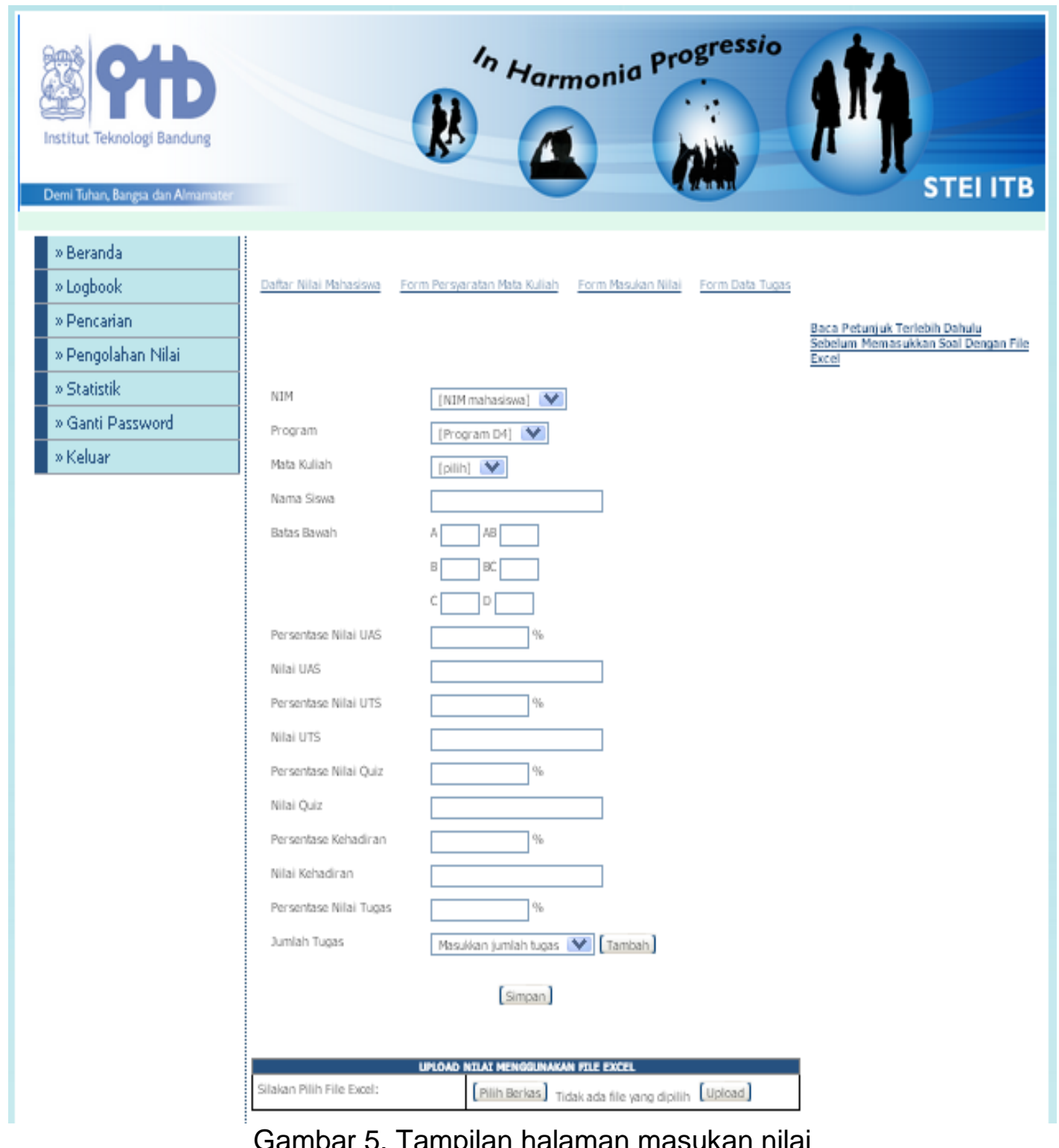

Pada gambar 6 , terlihat tampilan dosen memasukkan data prosentase nilai terdiri dari nilai tugas, nilai kuis, nilai UTS, nilai UAS dan nilai kehadiran dan syarat batas bawah nilai sesuai dengan mata kuliah. Apabila dosen memasukkan prosentase nilai dan jumlah dari prosentase nilai melebihi $100 \%$ atau kurang dari $100 \%$ maka ada pemberitahuan. Untuk itu, terdapat catatan yang menyatakan bahwa jumlah prosentase nilai harus $100 \%$. Untuk syarat batas bawah nilai, jika batas bawah nilai $A$ lebih kecil dari batas bawah nilai $A B$, batas bawah nilai $A B$ lebih kecil dari batas bawah nilai $B$, batas bawah nilai $B$ lebih kecil dari batas bawah nilai $\mathrm{BC}$, batas bawah nilai $\mathrm{BC}$ lebih kecil dari batas bawah nilai $\mathrm{C}$ dan batas bawah nilai $C$ lebih kecil dari batas bawah nilai $D$ maka terdapat pemberitahuan bahwa nilai yang dimasukkan salah. Apabila hal itu terjadi, dosen harus memasukkan ulang data persyaratan mata kuliah. 


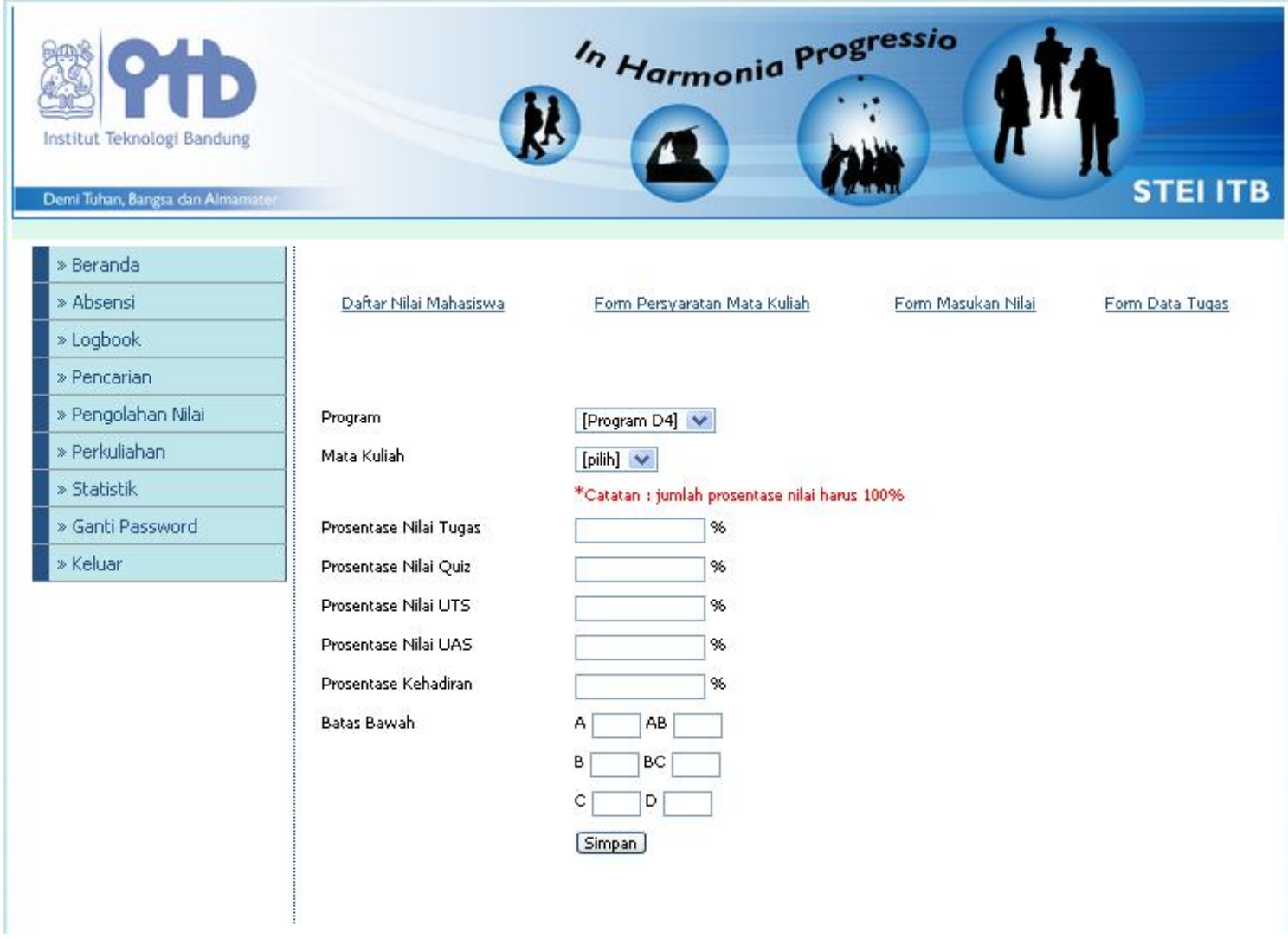

Gambar 6. Tampilan persyaratan mata kuliah

\section{PENUTUP}

Aplikasi pengolahan nilai pada produk ISMILeSys ini dirancang dengan menggunakan diagram alir. Pengguna yang menggunakan aplikasi ini adalah dosen. Dosen dapat memasukkan persyaratan mata kuliah pada setiap mata kuliah jika ingin mengubah dari yang telah ditetapkan sebagai standarnya. Dosen dapat memasukkan nilai, memperbaiki nilai dan memasukkan nilai remidial jika nilai mahasiswa di bawah standar atau jika diperlukannya remidial untuk mahasiswa yang bersangkutan serta dosen dapat menghapus nilai mahasiswa. Selain mengubah dan menghapus nilai mahasiswa, dosen dapat melakukan hal yang sama dengan tugas yang dikumpulkan mahasiswa. Sehingga, dosen mendapatkan nilai akhir setiap mahasiswa.

\section{DAFTAR PUSTAKA}

Castagnetto, J. et. Al., Professional PHP Programming, Wrox Press, 1999.

Ridwan M., Modul Pembelajaran Praktek Basis Data (MySQL), 2009. Diunduh dari http://buku-e.lipi.go.id, 10 April 2011, 14.00 WIB.

Willy B.S., Pemrograman PHP dan MySQL, 2008. Diunduh dari http://willy.situshijau.co.id, 16 April 2011, 11.02 WIB.

Diunduh dari http://www. deptan.go.id/pusdatin/admin/RB/Progr amming/Materi\%20PHP.pdf, 19 April 2011, 19.52 WIB. 